\title{
The Jurisdiction of the Federal Trade Commission
}

[NOTE-The Federal Trade Commission was created by Act of Congress approved September 26, 1914, ch. 311, $38 U$. S. Stats. at L. 717, N. S. Comp. Stat. \$\& 8836a-8836k. This article, discussing the jurisdiction of the Commission, was written as a chapter in a book to be published in the neat future by the author. The question when the Commission should take jurisdiction in cases of alleged unfair methods of competition in commerce is of increasing interest from the point of view of policy and of law.-EDrTor.]

\section{A. Public Interest.}

Section 5 of the Federal Trade Commission Act provides:

"Whenever the commission shall have reason to believe that any such person, partnership, or corporation has been or is using any unfair method of competition in commerce, and if it shall appear to the commission that a proceeding by it in respect thereof would be to the interest of the public, it shall issue and serve upon such person, partnership, or corporation a complaint stating its charges in that respect and containing a notice of a hearing upon a day and at a place therein fixed at least thirty days after the service of said complaint."

The question was raised whether the public interest be deemed a preliminary administrative consideration before instituting proceedings, or a question of fact to be determined by the Commission and included within its findings of fact. It would appear that the provisions of the statute favor the former view. The Act provides: "That unfair methods of competition in commerce are hereby declared unlawful." It includes all unfair methods of competition. Further, "The commission is hereby empowered and directed to prevent persons, partnerships, or corporations, except banks, and common carriers subject to the acts to regulate commerce, from using unfair methods of competition in commerce." Nothing is stated to exclude any unfair methods of competition in commerce from the jurisdiction of the Commission. After providing for notice the act dictates:

"If upon such hearing the commission shall be of the opinion that the method of competition is prohibited by this act, it shall make a report in writing in which it shall state its findings as to facts, and shall issue and cause to be served on such person, partnership, or corporation an order requiring such person, partnership, or corporation to cease and desist from using such method of competition." 
The provision "if it shall appear to the cammission that a proceeding by it in respect thereof would be of interest to the public" relates solely to the issuing of the complaint. If there is in fact a case of unfair methods of competition, the public interest is presumed in the aforementioned provisions of the act. The Clayton Act makes no mention at all of the public interest.

It may well be stated here that the question of the existence of the public interest must be interpreted as a question of the existence of sufficient public interest to warrant action by a public body. For it is inconceivable that the public may have no interest in matters affecting its economic life, no matter to what degree. This especially is the case if we consider that the public has an interest in such matters as education, sanitation, the use of intoxicating liquors, gambling, etc. The determination of the sufficiency of the public interest involved is solely an administrative question. The provision with reference to it vests in the Commission the discretion whether to proceed in a given case or not. Otherwise, as was argued by the Commission in Raymond Bros.-Clark Co. v. Federal Trade Commission,"5s "mandamus would probably lie to compel the Commission to hear and determine any case of the alleged use of unfair methods of competition (I. C. C. v. Humboldt Steamship Co., 224 U. S. 474) however slightly the matter touched the general public."

The determination of the question of "public interest" is a matter of discretion which the courts will not review. In Field v. Clark, ${ }^{58}$ it was contended that the Act of Congress in question in that case was unconstitutional because the words "which he may deem to be unequal and unreasonable" vested the President with legislative discretion in enforcing one law or another. The court held that the discretion involved referred merely to the finding as a matter of fact whether the duties were or were not reciprocally unequal and unreasonable. As soon as, upon examination of the commercial regulations of other countries, he found them to be unequal and unreasonable, or otherwise, he had no choice in applying the law. In Buttfield v. Stranahan, ${ }^{57}$ the Act of Congress in question directed the Secretary of the Treasury to prevent the importation of impure and unwholesome tea, but did not set the standards of quality to be

55 (1922) 280 Fed. 529.

55a Brief for Com'n in Supreme Court of the U. S. on writ of certiorari, p. 33, Case No. 102, October Term, 1923.

${ }_{58}$ (1892) 143 U. S. 649, 36 L. Ed. 294, 12 Sup. Ct. Rep. 495.

57 (1903) 192 U. S. 470,48 L. Ed. 525, 24 Sup. Ct. Rep. 349. 
applied by the Secretary. Referring to the standards adopted by the Secretary of the Treasury, the court said:

"The sufficiency of the standards adopted by the Secretary of the Treasury was committed to his judgment, to be honestly exercised, and if that were important, there is no assertion here of bad faith or malice on the part of that officer in fixing the standards, or on the part of the defendant in the performance of the duties resting on him. .... The provisions in respect to the fixing of standards and the examination of samples by government experts was for the purpose of determining whether the conditions existed which conferred the right to import .... This latter question was intended by Congress to be finally settled, not by a judicial proceeding, but by the action of the agents of the government, upon whom power on the subject was conferred.".77a

And if it be argued that these cases do not present a sufficient analogy to the question before us, then it must be urged that the assertion that this is wholly a matter within the discretion of the Federal Trade Commission is not without judicial authority. People v. Ballard ${ }^{68}$ presents the same probleins in the interpretation of section 1808 of the New York Code of Civil Procedure, which provides, that "where the Attorney General has good reason to believe that an action can be maintained in behalf of the people of the state . . . he must bring an action accordingly, if, in his opinion, the public interests require that an action should be brought." The defendant in that case urged that it is for the court to decide whether the public interests, in fact, required the action to be brought; in other words, that the question of public interest is an issuable fact. To this the court answered:

"We think that the question as to what the public interests require is committed to the absolute discretion of the attorney general, and that it cannot be made the subject of inquiry by the courts. If he abuses the great power intrusted to him, a remedy may be found in his removal from office, or in the election of a successor worthy of the high position."

That statute provided: "if, in his opinion, the public interests require . . . .;" the Federal Trade Commission Act provides: "if it shall appear to the commission that a proceeding by it in respect thereof would be of interest to the public ...." Wherein lies the difference?

s7a Idem, p. 497.

58 (1892) 134 N. Y. 269,32 N. E. 54.

s8a Idem, p. 293. 
But that has not been the view taken by the courts in the cases involving the Federal Trade Commission. The courts insisted that the facts found by the commission must disclose a public interest. What facts will, in the opinion of the courts, satisfy the requirement, can best be gathered from the decisions. Ward, $J$., in his decision of Federal Trade Commission v. Gratz, ${ }^{69}$ said:

"It seems to us that unfair methods of competition between individuals are not contemplated by the act. Congress could not have intended to submit to the determination of the commission such questions as whether a person, partnership or corporation had treated or bribed the employés of a competitor for the purpose of inducing them to betray their employer. We think the unfair methods, though not restricted to such as violate the AntiTrust Acts, must be at least such as are unfair to the public generally. It seems to us that section 5 is intended to provide a method of preventing practices unfair to the general public and very particularly such as if not prevented will grow so large as to lessen competition and create monopolies in violation of the Anti-Trust Acts. Such a preliminary inquiry and determination constitutes a inost important supplement in carrying out the public policy which those acts are intended to vindicate."158a

And in New Jersey Àsbestos Co. v. Federal Trade Commission, 60 dealing with bribery as an unfair method of competition, Ward, J., said :

"The payment of money or the giving of valuable presents to an employee to induce him to influence his employer to make a contract of purchase is a fraud justifying the discharge of the employee within his contract term of service, and perhaps the recovery by the purchaser of the amount or value of such inducement froin the seller upon the theory that it must have been included in the price. But even in such a case we think it would be a matter between individuals and not one so affecting the public as to be within the jurisdiction of the Commission under our decision in the Gratz case . . . . However, it stretches theory to the breaking point to suppose that the entertainment expenses found unfair in this case constitute fraud practiced by the respondent and by the employees on the purchasers of the respondent's goods. It is difficult to conceive that the purchaser would have a right to recover the amount of such entertainment as a part of the price paid for the goods bought, or that he would have a right to discharge the employee within the term of his service on this ground. So broad a construction of the statute would bring within the disposition of the Commission a vast

59 (1919) 258 Fed. 314.

s9a Idem, p. 316 .

${ }^{60}$ (1920) 264 Fed. 509. 
number of subjects and controversies which in their nature belong to the legislative and judicial departments of the government." Froin these statenents we may conclude that in the opinion of Ward, J., the Federal Trade Commission has no jurisdiction, unless and until a large part of the public has already been injured financially by the methods of competition complained of. No matter how abhorrent the method may be to the good morals of the people, as long as mere individuals are injured, the public is not affected, in spite of the fact that the public, through its governmental agencies, is constantly called upon to aid the unfairly competing business. The position taken by Ward, J., is on the positive side illustrated by his statement in Beech-Nut Packing Co. v. Federal Trade Commission, ${ }^{\text {BI }}$ dealing with the "Beech Nut System" of maintaining uniform prices:

"The subject is one affecting the public generally, and plainly within the jurisdiction of the Commission. The ground upon which the conclusion of law rests is that the method is unfair, because it stifles competition and so restrains trade. The obvious purpose of the respondent is to prevent any competition as to the resale price between purchasers of its products. Such a method, founded upon an agreement between a manufacturer and purchasers severally, was held to be in violation of the Sherman Act . . . in Dr. Miles Medical Co. v. Park \& Sons Co., 220 U. S. 373 .... It is difficult to say why a different conclusion should be reached, if the same result is attained by acquiescence and co-operation without express agreement between the manufacturer and his purchasers severally. Eastern States Retail Lumber Association v. United States, 234 U. S. 600 . . . ."101a

In short, the court would limit the jurisdiction of the Commission to cases where there is a violation of the Anti-Trust Acts or where there is proof that the public has alrcady been injured, under the supposition that the public has no concern with the methods employed by competing individuals. This is obviously not in accord with the provision of the statute "that unfair methods of competition in commerce are hereby declared unlawful." No distinction is made by the statute in favor of unfair methods of competition between individuals. Had Congress intended such a distinction, it would undoubtedly have said so.

The answer to the position taken by Ward, J., is contained in the dissenting opinion of Mr. Justice Brandeis in Federal Trade Commission v. Gratz. ${ }^{62}$ He says:

soa Idem, p. 511.

61 (1920) 264 Fed. 885.

61 Idem, p. 889.

${ }^{\circ}$ (1919) 253 U. S. 421, 64 L. Ed. 993, 40 Sup. Ct. Rep. 572. 
"The reason assigned by the Circuit Court of Appeals for so holding, was that the evidence failed to show that the practice complained of (although acted on in individual cases by respondents) had become their 'general practice.' But the power of the Trade Commission to prohibit an unfair method of competition found to have been used is not limited to cases where the practice had become general. What $\$ 5$ declares unlawful is not unfair competition. That had been unlawful before. What that section made unlawful were 'unfair methods of competition;' that is, the method or means by which an unfair end might be accomplished. The Commission was directed to act, if it had reason to believe that an 'unfair method of competition in commerce' has been or is being used. The purpose of Congress was to prevent any unfair method which may have been used by any concern in competition from becoming its general practice. It was only by stopping its use before it became a general practice, that the apprehended effect of an unfair method in suppressing competition by destroying rivals could be averted." ${ }^{22 a}$

In Winsted Hosiery Co. v. Federal Trade Commission, ${ }^{6 s}$ Ward, J., was of the opinion that false and misleading advertising or labeling is not the concern of the public, as long as an action at law by a party injured could not be maintained. Even if some consumers are misled by the advertising or labeling of the goods, it is not of interest to the public that the Commission proceed against such a practice. He says:

"In this case there was obviously no unfair method of competition as against other manufacturers of underwear. The labels were thoroughly established and understood in the trade. There was no passing off of the petitioner's goods for those of another manufacturer. There was no combination in restraint of trade nor any attempt to establish a monopoly. Manifestly no other manufacturer of underwear could have maintained a suit against the petitioner for unfair competition or for an injunction or damages under the anti-trust Acts. Assuming that some consumers are misled because they do not understand the trade signification of the labels, or because some retailers deliberately deceive them as to its meaning, the result is in no way connected with unfair competition, but is like any other misdescription or misbranding of products." $"$ esa

The decision was reversed in the Supreme Court. ${ }^{84}$ Apropos to the question of public interest the court, speaking through Mr. Justice Brandeis, said:

82a Idem, p. 441.

6s (1921) 272 Fed. 957.

bsa Idem, p. 960.

6* (1921) 258 U. S. 483, 66 L. Ed. 729, 42 Sup. Ct. Rep. 384. 
"This argument appears to have prevailed with the Court of Appeals; but it is unsound. The labels in question are literally false, and, except those which bear the word "Merino," are palpably so. All are, as the Commission found, calculated to deceive and do in fact deceive a substantial portion of the purchasing public. That deception is due primarily to the words of the labels, and not to deliberate deception by the retailers from whom the consumer purchases. While it is true that a secondary meaning of the word "Merino" is shown, it is not a meaning so thoroughly established that the description which the label carries has ceased to deceive the public; for even buyers for retailers, and sales people, are found to have been misled. The facts shows that it is to the interest of the public that a proceeding to stop the practice be brought. And they show also that the practice constitutes an unfair method of competition as against manufacturers of all wool knit underwear and as against those manufacturers of mixed wool and cotton underwear who brand their product truthfully ... That these honest manufacturers might protect their trade by also resorting to deceptive labels is no defense to this proceeding brought against the Winsted Company in the public interest.

"The fact that misrepresentation and misdescription have become so common in the knit underwear trade that most dealers no longer accept labels at their face value, does not prevent their use being an unfair method of competition. A method inherently unfair does not cease to be so because those competed against have become aware of the wrongful practice. Nor does it cease to be unfair because the falsity of the manufacturer's representation has become so well known to the trade that dealers, as distinguished from consumers, are no longer deceived. . . . the Commission was justified in its conclusion that the practice constituted an unfair method of competition; and it was authorized to order that the practice be discontinued."

Here we have two points of view which are well worth while considering, for upon the acceptance of the one or the other will depend the effectiveness of the Federal Trade Commission Act, as of other acts pertaining to the same subject matter. The question is, what constitutes sufficient public interest? There are two ways of determining the question in each particular case. First, by comparing the practice in question with such practices which have been the subject of governmental action, whether through legislative, executive, or judicial bodies. Second, through an investigation of those social phenomena which are involved in the practice and which do affect a considerable part of the public, whether collectively or distributively. The first method is useful, but limited. The second

osa Idem, p. 493. 
method is more extensive, but depends largely, not on legal questions, but on economic or social theory. On the one hand it may be claimed that public interest is not involved, unless an injury to the public is shown. On the other hand it may be asserted that wherever the use of social machinery is involved, there is present a public interest. These are the extreme views of the matter. Which, if either, should be adopted by the Federal Trade Commission is a matter of public policy. And if the legislature determines the public policy, it is for the Commission and the courts to give effect to it. In the present problem, the policy has been determined by the legislature in the Sherman Act, the Federal Trade Commission Act, and the Clayton Act. In effect it is that whenever the Commission has reason to believe that a person, partnership or corporation employs a method of competition which is unfair, and in the opinion of the Commission the public interest is sufficient, the Commission is under a duty to institute proceedings.

The conflict between the policy of the legislature as set forth and that of the courts is best illustrated in the cases involving the leasing of gasoline pumps. There it is conceded on both sides that the public interest is involved. It may well be admitted that the purchasing public finds the pumps a convenience. But together with it is involved a conflict of social values: the value of the convenience as opposed to the value of prohibiting "tying" contracts or leases. What value is to be accepted to the exclusion of the other is a matter of public policy. The Federal Trade Commission Act prohibits unfair methods of competition, the Clayton Act prohibits "tying" contracts. Can the courts upset that policy and adopt its antithesis? In Standard Oil Co. v. Federal Trade Commission, ${ }^{65}$ the Court said:

"The next contention of the petitioners .... meets the issue of public interest and is to the effect that the evidence fails to show that the public has been injured. With this we agree. Postpoming discussion of the effect of the practice upon competition and monopoly, we do not find that the practice has increased the cost of distribution or has enhanced the price of gasoline to the public. On the contrary it has decreased the cost of distribution. Whether the price to the public has been reduced, we cannot say. Clearly the public has found an advantage in the practice both in the matter of convenience and in the certainty of getting the precise make of gasoline advertised on the globe of the pump. On the other hand, if the orders of the Commission commanding the petitioners to cease and desist from the practice and thereafter to lease outfits to retailers only on remunerative

${ }^{65}$ (1922) 282 Fed. 81. 
rentals stand, the inevitable result will be that the number of curb filling stations will be reduced, thereby lessening the convenience to the public; or the rental charged the retailer for the outfit will be covered by fixing wholesale prices so as to allow him a larger profit. In the readjustment, the public doubtless will undergo its usual experience of paying higher prices."

And therefore the court held that the pump leases providing that none but the gasoline of the lessor be used in that pump are not so contrary to the public interest as to be included under the provisions of the Federal Trade Commission Act or the Clayton Act. It must be observed that the Clayton Act contains no mention at all of public interest, hence the public interest must at any rate be presumed; otherwise Congress would not have passed the law. Not to presume a public interest and on that ground refuse to give effect to it, would mean that the courts may not only declare laws unconstitutional but also agamst public policy. In the dissenting portion of his opinion, Morris, J., illustrates the conflict between the decision of the court and the provisions of the Act of Congress:

"With respect to the one pump retailer the restrictive clause in the leases in question is as effective in preventing the lessee froin using or dealing in the gasoline of a competitor of the lessor as if the lease expressly so provided. True, the lessee may terminate the lease at the time and under the conditions mentioned therein, but that fact does not enable the tying clause to elude the prohibition of section 3 of the Clayton Act, for that section operates with respect to short term leases and leases at will in like manner and with like force as it does with respect to long-term leases, or, for that matter, leases in perpetuity. The legality or illegality of the tying clause is dependent not at all upon the duration of the lease or the manner in which it may be terminated. It is likewise true that the lessee has the right to install another pump of his own or a pump of a competitor; but, as his business does not warrant or require more than one pump, he has not installed more than one, and, consequently, his right is not a practical one, but a mere abstract right. The result in my opinion is that in practice the restrictive clause of the leases in question has prevented and prevents a 'single pump' lessee froin using or dealing in gasoline of a competitor of the lessor just as effectively as if the lease had expressly so provided. Consequently, the lease falls within the prohibition of Section 3 of the Clayton Act if the effect of such lease 'may be to substantially lessen competition or tend to create a monopoly' in selling gasoline at wholesale. Whether its effect may be to substantially lessen competition or tend to create a monopoly is our second question for consideration. The leases are now in force. The

$65 \mathrm{adem}$, p. 85 . 
fact that they may be terminated at some future time is not relevant to the issue now under consideration. What has already been said shows that 'a large majority of the retailers' require for use in their business only a single pump outfit and the practical effect of the restrictive covenant of the lease under which they operate is to prevent such large majority from using or dealing in the gasoline of competitors of their respective lessors . . .

"The petitioners have set up as a reason for the reversal of the Commission's order the excellence of the pump as a means for storing and delivering gasoline ... But the Commission has not attacked the pump. On the contrary, it admits the pumps many advantages and great utility. It denies, however, the right of the petitioners to make unlawful contracts with respect thereto, or otherwise to use it as a means of stifling competition." 66

Without entering into the merits or demerits of the issues involved in these cases, it may well be observed that the question of public interest is one depending largely on questions of public policy, rather than law. And if it can be shown that as a matter of fact and law that the method of competition is unfair or that the practice complained of does tend to lessen competition or create a monopoly, the jurisdiction of the Commission is established.

\section{B. ConcurRent Jurisdiction with the Interstate COMMERCE COMMISSION}

An interesting question as to the jurisdiction of the Federal Trade Commission relates to practices of corporations under the jurisdiction of the Commission, but which practices are committed conjointly with corporations under the jurisdiction of the Interstate Commerce Commission. Section 11 of the Clayton Act provides:

"That authority to enforce compliance with sections two, three, seven and eight of this act by the persons respectively subject thereto is hereby vested: In the Interstate Commerce Commission where applicable to common carriers, in the Federal Reserve Board where applicable to banks, banking associations and trust conipanies, and in the Federal Trade Commission where applicable to all other character of commerce."

In Fruit Growers' Express, Inc. v. Federal Trade Commission, ${ }^{67}$ the petitioner entered into contracts with various railroad companies, and these contracts were found by the Commission to be in violation of section 3 of the Clayton Act. This might appear to be a case in which the subject matter is within the concurrent jurisdiction of the

66282 Fed. 81, 92.

67 (1921) 274 Fed. 205. 
Federal Trade Commission and the Interstate Commerce Commission. But the court held that-

"The words 'where applicable to common carriers,' in section 11 of the Clayton Act, must mean that where the facts involve common carriers, or the business of common carriers, then the jurisdiction is solely in the Interstate Commerce Commission. The action complained of involved common carriers and tended to very greatly affect their business. Respondent was therefore without jurisdiction." $67 \mathrm{a}$

The facts as found by the Commission disclosed that the petitioner had entered into contracts and engaged in conduct contrary to the provisions of the Clayton Act. As a matter of law it had been established by previous decisions that corporations like the Fruit Growers' Express, Inc. are not common carriers. ${ }^{68}$ Section 11 of the Clayton Act further provides that "Whenever the Commission ... shall have reason to believe that any person is violating or has violated the provisions of sections two, three, seven, and eight of this act it shall issue and serve upon such person a complaint stating its charges in that respect."

"It will be noticed that the statute does not require the Commission to join any person as a party other than the person whom it has reason to believe is violating or has violated the law. If Congress had deemed it essential to the effectual execution of its purpose, that all persons interested in the subject of the proceeding, or whose interests were affected by it, or whose contractual relations might be modified should be made parties, it would have been a very easy and simple matter to have said so."69

But in spite of the fact that the common carriers involved in the contracts are not necessary parties according to the provision of the Act, the court came to the conclusion that the words "where applicable to common carriers" mean that where the facts involve common carriers, etc., the jurisdiction is in the Interstate Commerce Commission. The conclusion is very odd, to say the least. For supposing that the Interstate Commerce Commission has proceeded against the petitioner, the court, following the same reasoning, might as well have said that the words "where applicable to all other character of commerce" must mean that where the facts involve such character of commerce other than common carriers, or the business of such other character of commerce, then the jurisdiction is in the Federal

t7a Idem, p. 207. Rep. 645 .

${ }^{68}$ Ellis v. I. C. C. (1914) 237 U. S. 434, 59 L. Ed. 1036, 35 Sup. Ct.

69 Fruit Growers' Express v. F. T. C., supra, n. 67. Brief for respondent, p. 26. 
Trade Commission, and that the Interstate Commerce Commission is therefore without jurisdiction. The logical result would then be that neither the Federal Trade Commission nor the Interstate Commerce Commission may have jurisdiction over such cases. All that would be necessary then to render the Clayton Act entirely impotent is for the violator of the law to make contracts, leases, engage in price discriminations, etc., which will in some way involve a common carrier. However, the Commission moved for a writ of certiorari, which was granted, ${ }^{70}$ but by that time the defendant had sold the cars to another corporation, and the new contracts did not contam any of the objectionable clauses. The Commission therefore moved for a dismissal of the case.

\section{Interstate Commerce}

The next question as to the jurisdiction of the Federal Trade Commission is most interesting. It involves the meaning of the words "interstate commerce." In Ward Baking Co. v. Federal Trade Commission, ${ }^{n}$ the court held that the petitioner, baking its bread in Cambridge, Massachusetts, shipping, it to Fall River, Massachusetts, and then transporting the bread in its wagons or trucks into Rhode Island, the wagons calling at the stores of retailers and selling the bread, is not selling it in interstate commerce. The practice complained of was that with each quantity of bread sold, the petitioner gave a proportionate quantity of bread gratis with the intent and purpose of forcing competitors out of business. This the Commission found to be an unfair method of competition. But the court ruled that that was not an unfair method of competition in commerce, hence the Commission is without jurisdiction. The decision was based on Wagner v. City of Covington, ${ }^{72}$ where under similar circumstances the Supreme Court of the United States held that such sales made by an Ohio corporation in Kentucky were subject to a license tax imposed by the City of Covington. But the two cases are widely different. A corporation doing interstate business may do things in any particular locality which would subject it to the laws of that locality. For example, a corporation doing interstate commerce and operating autonobiles within the state must pay a tax for operating

${ }^{70}$ F. T. C. v. Fruit Growers' Express (1921) 257 U. S. 627, 66 L. Ed. 405, 42 Sup. Ct. Rep. 56.

31 (1920) 264 Fed. 330.

72 (1919) 251 U. S. 95, 64 L. Ed. 157, 40 Sup. Ct. Rep. 93. 
such automobiles if the state law imposes such a tax. Or a corporation engaged in interstate commerce inay have to pay a tax on things it buys within a state, if the state imposes the tax on such commodities. Why should not such a corporation be subject to the license tax imposed within the state where it is doing business? The case did not rule and cannot be interpreted as having ruled that a person doing such business is not engaged in interstate cominerce. In fact, it was conceded that the respondent Wagner was engaged in interstate commerce while selling his wares. The question was whether the tax was a burden on interstate commerce. It has been decided time and again that such a tax is not a burden on interstate commerce, but merely subjects the person doing interstate commerce to the local laws and regulations applicable equally to everybody. Thus, in Woodruff v. Parham, ${ }^{73}$ the court decided that a uniform sales tax imposed by a state on all sales made in it, whether by a citizen of the state or of a foreign state or whether the goods sold are the products of the state or of a foreigu state is valid. Mr. Justice Miller, speaking for the court, said:

"The case before us is a simple tax on sales of merchandise . . . . by citizens of Alabama." "rsa

And even if the mode of collecting the tax on articles made without the state is different from that applied to articles made within the state, the tax is not unconstitutional as long as the amount is not discriminatory. ${ }^{74}$ And in Howe Machine Co. v. Gage, ${ }^{75}$ a license tax imposed on all peddlers of sewing machines without regard to the place where the machines coine from has been held constitutional, as long as the tax is not discriminatory against interstate commerce and is not so unreasonable as to constitute a burden on interstate commerce. Accordingly, in Plumley v. Massachusetts, ${ }^{78}$ the Court held that a statute in Massachusetts prohibiting the sale of oleomargarine colored to imitate butter, was constitutional as applied to the sale of oleomargarine imported from another state.

None of these cases hold that the sales subjected to taxation or prohibition are not in interstate commerce. The reason for the decisions is that there is no discrimination or direct burden on inter-

73 (1868) 75 U. S. (8 Wall.) 123, 19 L. Ed. 449.

$73 a$ Idem, p. 140 .

74 Hinson v. Lott (1868) 75 U. S. (8 Wall.) 148, 152, 153, 19 L. Ed. 387.

${ }^{75}$ (1879) 100 U. S. 676, 679, 25 L. Ed. 754; see also Emert v. Missouri (1894) 156 U. S. $296,311,39$ L. Ed. 430,15 Sup. Ct. Rep. 367.

${ }_{78}$ (1894) 155 U. S. 461, 468, 471-474, 39 L. Ed. 223, 15 Sup. Ct. Rep. 154. See also Leisy v. Hardin (1889) 135 U. S. 100, 34 L. Ed. 128, 10 Sup. Ct. Rep. 681 . 
state commerce. And in the case of Wagner v. City of Covington, ${ }^{17}$ Mr. Justice Pitney does not hold that the sales are in intrastate commerce. The reason for his decision is contained in the following words:

"We have, then, a state tax upon the business of an itinerant vendor of goods as carried on within the State, a tax applicable alike to all such dealers, irrespective of where their goods are manufactured, and without discrimination against goods manufactured in other States. It is settled by repeated decisions of this court that a license regnlation or tax of this nature, imposed by a State with respect to the making of such sales of goods within its borders, is not to be deemed a regulation of or direct burden upon interstate commerce, although enforced impartially with respect to goods manufactured without as well as within the state, and does not conflict with the 'commerce clause'."77a

That this is the reason for the decision, and not that Wagner was engaged in intrastate commerce while making those sales is further proved by the fact that in all similar cases where there is discrimination against or a burden on interstate commerce, the law has been held unconstitutional. ${ }^{78}$ Thus, a state may not impose a higher tax upon peddlers from another state than is imposed upon her own citizens. $^{79}$ The law on the subject is most ably summarized by $\mathrm{Mr}$. Chief Justice Taft, in Sonneborn Bros. v. Cureton, ${ }^{80}$ as follows:

"A state tax upon merchandise brought in from another State or upon its sales, whether in original packages or not, after it has reached its destination and is in a state of rest, is lawful only when the tax is not discriminating in its incidence against the merchandise because of its origin in another State. This distinction is illustrated in the difference between those cases which uphold the validity of a tax upon peddlers engaged in selling merchandise from out of the State which they carry with them, like those of Machine Co. v. Gage, 100 U. S. 676, Emert v. Missouri, 156 U. S. 296, Baccus v. Louisiana, 232 U. S. 334, and Wagner v. Covington, 251 U. S. 95, on the one hand, and that of Welton v. Missouri, 91 U. S. 275, in which a peddler's tax was held bad because it was levied only on goods from other States, on the other." "80a

It is urged, however, that what section 5 of the Federal Trade Commission Act prohibits is "unfair methods of competition in com-

77 Supra, n. 72.

7т2251 U.. S. 95, 102.

${ }^{78}$ Askren v. Continental Oil Co. (1919) 252 U. S. 444, 64 L. Ed. 654, 40 Sup. Ct. Rep. 355.

79 Ward v. Maryland (1870) 79 U. S. (12 Wall.) 163, 418, 20 L. Ed. 743.

See also Guy v. Baltimore (1879) 100 U. S. 434, 442, 443, 25 L. Ed. 260.

80 (1923) 262 U. S. 505, 67 L. Ed. 665, 43 Sup. Ct. Rep. 443.

s0a Idem, p. 516. 
merce," and hence the jurisdiction of the Federal Trade Commission depends not on whether the person complained of is engaged in interstate commerce and using unfair methods of competition in the conduct of his business, but whether the particular act complained of taken separately constitutes interstate commerce. And since the court did not consider that the sale which took place from the wagons to the stores was an act in interstate commerce, the unfair methods employed were not within the jurisdiction of the Commission. The Court in the Ward Baking Co. case is either committing a logical fallacy or is putting a narrow construction on the term "coininerce." If a law prohibits an act in a city, the accused cannot claim immunity from prosecution on the ground that he committed the act in a house located in the city. The relation between the act of selling or transferring title to the bread and the business of the Ward Baking Co. is that of inclusion. If there was an unfair method of competition used in any act in the conduct of the business, it is an unfair method of competition in the business. This is on the assumption that "commerce" is given its accepted meaning. If, however, the position of the Court is based on a narrow interpretation of the term "commerce," namely, that each act in the course of the business is to be considered by itself, then it must be argued that interstate commerce must be involved only in the act of crossing the state line. Such a position is untenable, and is contrary to that taken by the Supreme Court in defining commerce as including the purchase, sale and exchange of commodities, as well as their transportation. ${ }^{81}$ Thus, in Gibbons v. Ogden, ${ }^{82}$ the Court said:

"Commerce, in its simplest signification, means an exchange of goods; but in the advancement of society, labor, transportation, intelligence, care, and various mediums of exchange, become cominodities, and enter into commerce; the subject, the vehicle, the agent, and their various operations, become the objects of commercial regnlation."

And this is supplemented by the all inclusive statement in DahnkeWalker Milling Co. v. Bondurant, ${ }^{33}$ that "commerce among the states within Constitution, article 1 , paragraph 8 , clause 3 , is not

81 Pensacola Tel. Co. v. Western Union Tel. Co. (1877) 96 U. S. 1, 24 L. Ed. 708; Welton v. Mo. (1875) 91 U. S. 275, 23 L. Ed. 347; Gloucester Ferry Co. v. Penn. (1884) 114 U. S. 196, 29 L. Ed. 158, 5 Sup. Ct. Rep. 826; Addyston Pipe \& Steel Co. v. U. S. (1899) 175 U. S. 211, 44 L. Ed. 136, 20 Sup. Ct. Rep. 96; Rosenberger v. Pacific Express Co. (1915) 241 U. S. 48, 60 L. Ed. 880, 36 Sup. Ct. Rep. 510.

82 (1824) 92 U. S. (9 Wheat.) 1, 5 L. Ed. 191.

828 Idem, p. 229.

83 (1921) 257 U. S. 282, 66 L. Ed. 239, 42 Sup. Ct. Rep. 106. 
confined to transportation from one state to another, but comprehends all commercial intercourse between the different states, and all component parts of such intercourse. If, in accordance with these definitions of commerce, it is still maintained that the Ward Baking Co. is not engaged in interstate commerce while selling its bread in Rhode Island, it is indeed difficult to see a distinction between interstate and intrastate commerce. It cannot be that the decision in the Ward Baking Co. case meant to convey that had the Ward Baking Co. shipped its goods by rail and made the sales from and at the freight car, that would have been interstate commerce. Should the mode of transportation, then, determine whether the particular act is in interstate or intrastate commerce? If that be the case, then the corporations doing a nation-wide business may at very small expense evade any federal legislation subjecting them to regulation.

This question of the jurisdiction of the Federal Trade Commission is further illustrated in Winslow v. Federal Trade Commission and Norden Ship Supply Co. Inc. v. Federal Trade Commission, ${ }^{84}$ in which the Circuit Court of Appeals held that ship-chandlers furnishing supplies to foreign ships are not engaged in interstate or foreign commerce. The facts of the cases are as follows: Winslow \& Co. is a partnership with its principal offices and places of business in Norfolk and Newport News, Virginia. The Norden Ship Supply Co. Inc. is a corporation of New York, with its principal offices in Baltimore, Maryland, and branch stores or warehouses in New York, Philadelphia, Norfolk, Newport News and Savannah. The respective companies send representatives into foreign countries to solicit business of ship owners, and enter into contracts with them for the sale of supplies. When a ship arrives in port, the captain usually visits one of the stores and selects supplies for the ship. Payment is afterwards made by agents of the shipowner. About ninety per cent of the business done by the Winslow Co. is with English ships, while most of the business of the Norden Ship Supply Co. is done with Scandinavian vessels. The practice complained of was that these companies, to induce the ships to deal with them, gave the captains secret commissions and gratuities without the knowledge or consent of their employers.

As a preliminary matter it had to be determined whether these ship-chandlers were engaged in interstate or foreign commerce. The Commission argued that since these ship-chandlers purchase their

84 (1921) 277 Fed. 206. 
products throughout the United States and make executory contracts in foreign countries for the sale of such products, and since their trade is with ships engaged in coastwise and foreign commerce, they are engaged in interstate and foreign commerce, although the particular act of passing title to the goods takes place within the state. ${ }^{85}$ For "negotiation of sales of goods which are in another state, for the purpose of introducing them into the state in which the negotiation is made, is interstate commerce," and because "Commerce briefly stated is the sale or exchange of commodities. But that which the law looks upon as the body of commerce is not restricted to specific acts of sale or exchange. It includes the intercourse-all the initiatory and intervening acts, instrumentalities and dealings-that directly bring about the sale or exchange."

The court did not so regard the question raised. As in the Ward Baking Co. case the court looked not to the whole business, but to the particular transactions, and held that the business of the shipchandlers above mentioned did not constitute interstate or foreign commerce:

"In carrying on the business thus outlined, were the petitioners engaged in interstate or foreign commerce? This is the fundamental question to be determined, since if they were not, the Commission was without jurisdiction. The claim that they were engaged in interstate commerce rests wholly on the fact that the commodities in which they deal are in large part transported into Virginia from other states in which they are produced. But this transportation ends when the goods reach their destination and are placed in petitioners' warehouses in Norfolk and Newport News. They are then incorporated in the general stock of merchandise there held for sale, and become subject, so far as now concerns us, to the exclusive jurisdiction of the State of Virginia. Their subsequent sale and delivery within that state, with which alone the condemned practices are connected, is in no sense interstate commerce. In short, it is quite beyond doubt that the jurisdiction of the commission over the matter in hand cannot . be supported by the prior, but independent and completed transportation of the goods, or some part of them, from another state ....

85 Dozier v. Ala. (1909) 218 U. S. 124, 128, 54 L. Ed. 965, 30 Sup. Ct. Rep. 649; Penn. R. R Co. v. Clark Coal Co. (1914) 238 U. S. 456, 466, 59 L. Ed. 1406, 35 Sup. Ct. Rep. 896.

86 Robbins v. Shelby Taxing District (1886) 120 U. S. 489, 497, 30 L. Ed. 694, 7 Sup. Ct. Rep. 592; Caldwell v. N. C. (1902) 187 U. S. 622, 47 L. Ed. 336, 23 Sup. Ct. Rep. 229 ; Rearick v. Penn. (1906) 203 U. S. 507, 51 L. Ed. 295, 27 Sup. Ct Rep. 159; Crenshaw v. Ark. (1912) 227 U. S. 389, 396, 57 L. Ed. 565, 33 Sup. Ct. Rep. 294; Weeks v. U. S. (1917) 245 U. S. 618, 622, 62 L. Ed. 513, 38 Sup. Ct. Rep. 219. 87 U. S. v. Swift (1903) 122 Fed. 529, 531. 
"Were the petitioners engaged in foreign commerce? Their business is simply this: From stocks held in their storehouses in Virginia they sell and deliver supplies to ships lying in Hampton Roads, within the territorial limits of Virginia ; that is, in waters under the jurisdiction of that state. The Abby Dodge, 223 U. S. 166 ... Their dealings in all cases are carried on and concluded in the state of Virginia . . . This being so, how can it be said that the petitioners are engaged in foreign commerce? Surely not because, and solely because, the ships to which they sell supplies in a Virginia port go from that port to foreign countries. The mere statement of the facts refutes the contention ...

"The circumstance that many and perhaps most of the sales in question are brought about by solicitation of the shipowners in England, and contracts entered into with them in that country, cannot serve to make foreign commerce of the business carried on by the petitioners. ... . The petitioners send no goods abroad either as principals or agents or otherwise. The ships transport nothing for them or belonging to them or in which they are interested. Between them and the ships there is no relation of shipper and carrier, but only the relation of vendor and vendee. It therefore can make no difference, as respects the matter in dispute, whether the supplies are furnished under contracts previously made in England or under contracts made at the time with 'free ships' in Norfolk harbor.".87a

This limited view of foreign commerce is not consistent with that taken by the Supreme Court of the United States in Texas and New Orleans R. R. Co. v. Sabine Tram Co., ${ }^{88}$ namely, that shipment of freight under a local bill of lading, to be delivered to shippers' or consignees' order, but intended for export is foreign commerce. It must be noted that the foreign commerce starts with the original shipment of goods intended for export. ${ }^{89}$ The principle at the basis of these decisions is that "it is the essential character of the commerce, not the accident of local or through bills of lading, which determines Federal or State control over it. And it takes character as interstate or foreign commerce when it is actually started in the course of transportation to another state or to a foreign country."

The court, in the ship-supply cases, says that since the transactions of the companies begin and end within the territorial limits of

87a 277 Fed. 206, 209.

\$8 (1913) 227 U. S. 111, 123, 57 L. Ed. 442, 33 Sup. Ct. Rep. 229.

89 S. P. Terminal Co. v. I. C. C. (1910) 219 U. S. 498, 55 L. Ed. 310, 31 Sup. Ct. Rep. 279; Coe v. Errol (1885) 116 U. S. 517, 29 L. Ed. 715, 6 Sup. Ct. Rep. 475 .

90 La. R. R. Comm. v. Texas \& Pac. Ry. (1912) 229 U. S. 336, 341, 57 L. Ed. 1215, 33 Sup. Ct. Rep. 837; see also, Ohio R. R. Com. v. Worthington (1911) 225 U. S. 101, 109, 56 L. Ed. 1004, 32 Sup. Ct. Rep. 653. 
the state, they are not engaged in foreign commerce. That may be answered by a reference to the case of Spalding \& Bros. v. Edwards. ${ }^{91}$ There the plaintiff shipped goods to a commission merchant who was buying them for export, and the question was whether the plaintiff was engaged in foreign commerce. The plaintiff's transaction was with the commission merchant, not with his customer; the goods were consigned to him; he could have diverted the goods from the intended course; as far as the plaintiff was concerned, his transaction ended within the territorial limits of the state. Yet, the court held that the shipment was in foreign commerce, and hence subject to the tax imposed, because when the goods left the plaintiff they were intended for export. If that is foreign commerce, there can be no escape from the conclusion Winslow \& Co. and Norden Ship Supply Co. were engaged in foreign commerce, for in these cases there is not even an intervening party, like the commission merchant, to end the transaction for the ship supply companies within the state.

It is the essential character of the transaction that determines whether the goods are or are not in foreign commerce. Surely, it cannot be urged that the ship-chandlers did not intend the goods to be carried out of the state, over the seas and from port to port. Furthermore, if the contract between the commission merchant and his customer, in the Spalding \& Bros. case, and the plaintiff's knowledge of that contract is sufficient evidence of the intention to export the goods, a fortiori the contracts of the ship-chandlers and their own customers in foreign countries is sufficient evidence of the same. It matters not whether the contracts were conclusive contracts of sale, or whether they were mere options. They throw conclusive light on the character of the transaction. The ship-chandlers are supplying ships that carry the supplies out of the state for consumption. If the ships were to consume the supplies within the state, it would be to the immediate interest of the ship-chandlers to supply them anew for their voyage out of the state.

\section{Intrastate Commerce Affecting Interstate Commerce}

Another phase of the question of interstate commerce is presented by the Canfield Oil Co. v. Federal Trade Commission. ${ }^{92}$ The petitioner in this case was doing intrastate business, but its com-

91 (1923) 262 U. S. 66, 69-70, 43 Sup. Ct. Rep. 653.

82 (1921) 274 Fed. 571. 
petitors were engaged in interstate commerce. The Commission found that such intrastate commerce would be a great burden on the interstate business, if section 3 of the Clayton Act were applied to these competitors. The Commission therefore claimed jurisdiction over the petitioner under the doctrine announced in the Minnesota Rate Cases, ${ }^{93}$ namely,-

"When the situation becomes such that adequate regulation of interstate rates cannot be maintained without imposing requirements with respect to such intrastate rates of interstate carriers as substantially affect interstate rates, it is for Congress to determine, within the limits of its constitutional authority over interstate coininerce and its instruments, the measure of the regulation it should apply,"93a

and in Houston \& Texas Ry. v. United States, ${ }^{94}$ known as the Shreveport rate case, namely:

"Wherever the interstate and intrastate transactions of carriers are so related that the government of the one involves the control of the other, it is Congress, and not the State, that is entitled to prescribe the final and dominant rule, for otherwise Congress would be denied the exercise of its constitutional authority and the State, and not the Nation, would be supreme within the national field." $94 a$

The Circuit Court of Appeals, however, denied the jurisdiction of the Federal Trade Commission in this case.

The same question was brought up in Federal Trade Commission v. Claire Furnace Co. $^{95}$ Congress appropriated a sum of money that the Cominission may-

"proceed to the collection and publication of such information with respect to such basic industries as the said appropriation and other funds at its command will permit, and that such action. be started as soon as possible with respect to the coal industry and the steel industry, including in the latter closely related industries such as iron ore, coke, and pig-iron industries." ${ }^{958}$

To this end the Commission, under the authority of section 6 , subdivisions (a) and (b), issued order to the appellees, coal companies, requiring them to report the monthly costs of production for the several products designated and other data as specified in the form prescribed. The Commission also ordered the appellees to submit their accounts and books for inspection to enable it to check

93 (1912) 230 U. S. 352, 57 L. Ed. 1511, 33 Sup. Ct. Rep. 729.

93a Idem, p. 431.

94 (1913) 234 U. S. 342, 58 L. Ed. 1341, 34 Sup. Ct. Rep. 833.

94a Idem, p. 351.

95 (1923) 285 Fed. 936.

s5a Idem, p. 938. 
the reports which the appellees were required to furnish from time to time. Upon refusal to comply with the order, the Commission notified the companies that if they should persist in their failure to comply they would be subject to the penalty imposed by section 10 , clauses 1 and 3 , which provide:

"That any person who shall neglect or refuse to attend and testify, or to answer any lawful inquiry, or to produce documentary evidence, if in his power to do so, in obedience to the subpoena or lawful requirement of the commission, shall be guilty of an offense and upon conviction thereof by a court of competent jurisdiction shall be punished by a fine of not less than $\$ 1,000$ nor more than $\$ 5,000$, or by imprisonment for not more than one year, or by both such fine and imprisonment.

"If any corporation required by this act to file any annual or special report shall fail so to do within the time fixed by the commission for filing the same, and such failure shall continue for thirty days after notice of such default, the corporation shall forfeit to the United States the sum of $\$ 100$ for each and every day of the continuance of such failure, which forfeiture shall be payable into the Treasury of the United States, and shall be recoverable in a civil suit in the name of the United States brought in the district where the corporation has its principal office or in any district in which it shall do business. It shall be the duty of the various district attorneys, under the direction of the Attorney General of the United States, to prosecute for the recovery of forfeitures. The costs and expenses of such prosecution shall be paid out of the appropriation for the expenses of the courts of the United States."

The appellees applied to the Supreme Court of the District of Columbia to enjoin the Federal Trade Commission from further proceeding in the matter on the ground that the appellees were engaged in interstate and intrastate business, and that the information sought by the Commission concerned production and manufacturing which are of intrastate character. The answer of the Commission averred that with the exception of the companies named, "sixty-five per cent. or more of the sales made by each of complainants is in interstate or foreign commerce, and that the greater portion of the principal raw materials of each concern is purchased and transported in interstate commerce to their converting plants." The injunction was granted and the Commission appealed. It was the contention of the Commission that the "inquiry here involved is based upon the power of Congress to secure information concerning any subject matter in regard to which it has been given the power to legislate, and upon the further proposition that, when one phase of a subject 
matter is within the jurisdiction of Congress, it possesses the power to secure information as to the whole of the subject matter as a guide to further legislation."

The Court of Appeals of the District of Columbia, speaking through Associate Justice Van Orsdel, ${ }^{96}$ was of the opinion that the Federal Trade Commission was without jurisdiction:

"The authority of the Commission, we think, is limited by the acts of Congress to investigating and reporting upon unfair methods of competition in interstate commerce, .... The powers of the Commission are limited to matters directly relevant to interstate commerce. In other words, the corporation under investigation must not only be engaged in interstate commerce, but the subject under investigation must be so related to interstate commerce that its regulation may be accomplished by act of Congress. Where the operations of a corporation, engaged in both interstate and intrastate commerce, are so interwoven and intermingled as to be inseparable, it may be conceded that in order to regulate interstate commerce, the intrastate phases may be subjected to regulation and possible restriction, since the whole subject is thus brought within the jurisdiction of Congress."

But Mr. Justice Van Orsdel does not find that to be the case here. He distinguishes three separate and distinct operations involved in the business of the appellees: (1) The shipment of raw materials to plants, which is not interstate commerce; (2) the process of manufacture, which is not interstate commerce; and (3) the sale and delivery of the finished product. That is not interstate commerce until the goods are delivered to the carrier. Consequently, the implication is that the only subject for investigation within the jurisdiction of the Federal Trade Commission is the shipment of the goods through a common carrier across the state line. Whatever happens to the goods before or after the shipment is of no concern to the Federal government. This, as was noted in connection with the Ward Baking Co. case, ${ }^{97}$ is based on a narrow construction of interstate commerce, and is contrary to the economic conditions of a country where the economic units do not operate or are not restricted within the state lines. The conclusion of Mr. Justice Van Orsdel concerning the operations in the appellees' business which do not constitute interstate commerce may well be carried to all the other components of the business, concerning which the law authorizes the Federal Trade Commission to institute "investigation. If the assembling of raw materials, production and sales in a nation-wide 
business are not parts of interstate commerce, then surely the organization of the business is not interstate commerce; nor the conduct or practices, except in the process of selling and transhipping the goods; and surely not the management of the corporation. As to the reports the Commission may require, these must be limited to the sales and shipments across the state lines. The logical effect of the decision is to almost nullify section 6 , subdivisions (a) and (b). For Congress has directed the Commission to investigate the corporations, not only those acts of the corporations which taken by themselves would constitute interstate commerce.

The conclusion reached by Mr. Justice Van Orsdel to the effect that the inter and intrastate elements of commerce are not interwoven and may be easily separated is open to doubt. It is one thing to be able to name the various steps in the conduct of a business; it is quite another matter to state that these steps exert no direct influence on each other. When the raw materials are assembled and the finished products made, they are not intended to remain within the state. They are intended for immediate sale and shipment to all parts of the United States. In Stafford v. Wallace, ${ }^{88}$ it was held that the business done in the stockyard is subject to Federal regulation in spite of the fact that title passes within the state. The former owner may abandon all interest there and the new owner immediately divest himself of title. Yet the effect on interstate commerce is such that the Federal Government has power to regulate it. ${ }^{99}$ A fortiori, the facts sought by the Federal Trade Commission should be within the control of the Federal Government. Here title does not pass, the assembling of raw materials and their manufacture into the finished product directly influence and are influenced by the sales made. Any combination or agreement with reference to the former will have a distinct effect on the latter. In fact, it is difficult to see how Congress can obtain any adequate knowledge concerning the sales and profits made in interstate commerce, unless it correlates the same with the facts concerning the gathering of raw materials and the manufacturing involved.

98 (1922) 258 U. S. 495, 516, 66 L. Ed. 735, 42 Sup. Ct. Rep. 397.

99 It may be argued that the decision was based on statutory construction, since the Packers and Stockyards Act defines interstate commerce to include all transactions which are a part of the current of commerce beginning with the shipment of livestock with the expectation that they will end their transit, after purchase, in another state. But Congress cannot define as interstate commerce that which is not. Furthermore, the definition of commerce in the Packers and Stockyards Act is based on the decision of the Supreme Court in Swift \& Co. v. U. S. (1905) 196 U. S. 375, 49 I. Ed. 518, 25 Sup. Ct. Rep. 276. 
One of the reasons assigned by Mr. Justice Van Orsdel begs the question. He says :

"Complainant companies are engaged in a competitive productive industry, similar to the woolen or cotton manufacturers and those engaged in numerous other industries, where the business is regulated by competition and supply and demand, and the product enters into the general volume of commerce, subject to all the natural laws and conditions which generally govern and affect trade."

But that is a conclusion that can be reached only after a study of the facts which the Commission is seeking to obtain. Is the commerce in this case subject to the natural laws and conditions? If this were a criminal case, it would be reasonable to assume that such are the facts; but when the court makes such a categorical. statement in an equity proceeding, it assumes not only the conclusion of the case, but also the conclusion of the possible investigation.

The decision of the case appears to set a limit to the authority of Congress to regulate intrastate commerce. But the question of regulation need not enter at all. As was stated by Mr. Chief Justice Smyth in his dissenting opinion:

"The requiring of information concerning a business is not a regulation of that business. Interstate Commerce Commission v. Goodrich Transit Co., 224 U. S. 194, 211, 32 Sup. Ct. 436, 56 L. Ed. 729. In that case reports were called for by the Commission with respect to intrastate business. The corporation refused to supply it, on the ground that the Commission had no power to demand such information, because it related to intrastate business. But the court said that, since the information was essential to enable the Commission to perform its required duties touching interstate commerce, the Commission had a right to require it .... .

"It is beyond dispute that Congress has no general visitorial powers over state corporations, but it has been decided that it has power to visit them for the purpose of seeing 'that its own laws are respected.' Wilson v. United States, 221 U. S. 361, 384, 31 Sup. Ct. 538, 55 L. Ed. 771, Ann. Cas. 1912D, 558. By a parity of reasoning may it not be said that if it is necessary to protect interstate commerce, or appropriate for that purpose, that Congress should enter the field of intrastate commerce, it may do so? Houston \& Texas Railway Co. v. United States, 234 U. S. 342 , 34 Sup. Ct. 833, 58 L. Ed. 1341..$^{\text {9 }}$

99a 285 Fed. 936, 943.

90b Idem, p. 947. 


\section{E. Power to Issue Orders in Cases Where the Respondent Had Ceased the Practice Complained of}

Closely allied with the question of jurisdiction is the question whether the Commission has power to issue an order to cease and desist against persons, partnerships or corporations, who, before the commencement of proceedings against them, had already ceased the practice complained of. The statute provides that-

"Whenever the commission shall have reason to believe that any such person, partnership, or corporation has been or is using any unfair method of competition in commerce, and if it shall appear to the commission that a proceeding by it in respect thereof would be to the interest of the public, it shall issue and serve upon such person, partnership, or corporation a complaint stating its charges in that respect and containing a notice of a hearing upon a day and at a place therein fixed at least thirty days after the service of said complaint."

Sears. Roebuck \& Co. ${ }^{100}$ were circulating false and misleading advertisements, and were proceeded against by the Commission. The respondents claimed that no order should issue against them because they had already discontinued the practice and did not intend to resume it. The Court in commenting on this argunent said:

"Petitioner insists that the injunctional order was improvidently issued because, before the complaint was filed and the hearing had, petitioner had discontinued the methods in question, and, as stated in its answer, had no intention of resuming them. For exainple, no sugar offers of the character assailed were inade after August, 1917. But respondent was required to find from all the evidence before it what was the real nature of petitioner's attitude. It was permissible for respondent to take judicial notice of the government's war-time control of sugar sales and consuinption. It was also proper to note that petitioner was contending (and still contends) that the act is void for indefiniteness, that the act is unconstitutional, and that the act, even if valid, under any proper construction has not been infringed by petitioner's practices. In Goshen Mfg. Co. v. Myers Mfg. Co., 242 U. S. 202, 37 Sup. Ct. 105, 61 L. Ed. 248, which was a suit for infringennent of a patent, the defendant company averred and introduced evidence to prove that six months before the bill was filed and with notice to complainant it had sold its factory, wound up its business, and had no intention of resuming. But throughout the intervening period and also in the answer to the bill, the defendant company was attacking the validity of the patent and the right of the complainant to compel desistance. This conduct was held to be such a continuing menace as to justify the maintenance of the

100 Sears Roebuck \& Co. v. F. T. C. (1919) 258 Fed. 307. 
bill. So here, no assurance is in sight that petitioner, if it could shake respondent's hand from its shoulder, would not continue its former course."100a

The same was held in Juvenile Shoe Co. v. Federal Trade Commission $^{101}$ and in Guarantee Veterinary Co. v. Federal Trade Commission. ${ }^{102}$ The fact that the respondent had ceased to commit infringing acts is no evidence that he will not resume the same. The Commission is therefore empowered to issue an order to cease and desist at least where the respondent questions the validity of the proceedings.

\section{F. Sufficiency of the Complaint}

Since the complaint gives jurisdiction to the Commission in its proceedings, the sufficiency of the complaint may be regarded as a jurisdictional, or, at any rate, a quasi-jurisdictional question. It came up in the decision of the Supreme Court in Federal Trade Commission v. Gratz, ${ }^{103}$ in which Mr. Justice McReynolds held that since the complaint against the respondents does not state facts sufficient to show an unfair method of competition, the Commission had no jurisdiction $a b$ initio.

"It is unnecessary now to discuss conflicting views concerning validity and meaning of the act creating the commission and effect of the evidence presented. The judgment below must be affirmed since, in our opinion, the first count of the complaint is wholly insufficient to charge respondents with practicing "unfair methods of competition in commerce" within the fair intendment of those words. We go no further and confine this opinion to the point specified ....

"If, when liberally construed, the complaint is plainly insufficient to show unfair competition within the proper meaning of these words there is no foundation for an order to desist-the thing which may be prohibited is the method of competition specified in the complaint."103a

Mr. Justice Brandeis dissenting, took the position first, that since the question of pleading was not raised until the case came before the Supreme Court on the merits of the Commission's order, and since no objection to the complaint was raised by the respondent, there was no reason for considering the sufficiency of the pleadings before the Commission; second, that in proceedings against respondents insti-

100a 258 Fed. 307, 310.

101 (1923) 289 Fed. 57.

102 (1922) 285 Fed. 853.

${ }_{108}$ (1920) 253 U. S. 421, 64 L. Ed. 993, 40 Sup. Ct. Rep. 572.

$108 \mathrm{I}$ Idem, p. 426. 
tuted by administrative bodies it is not imperative that the complaint conform to the strict formality of an indictment or even a declaration. in a court; and third, that the complaint instituted by the Commission was sufficient. He said:

"The pleading held defective is not one in this suit. It is the pleading by which was originated the proceeding before the Federal Trade Commission, an administrative tribunal, whose order this suit was brought to set aside. No suggestion was made in the proceeding before the Commission that the complaint was defective. No such objection was raised in this suit in the court below. It was not made here by counsel. The objection is taken now for the first time and by the court.

"If the sufficiency of the complaint is held to be open for consideration here, we should, in iny opinion hold it to be sufficient. The complaint was filed under $\$ 5$ of the Federal Trade Commission Act which declares unlawful 'unfair inethods of competition in commerce'; empowers the Commission to prevent their use; and directs it to issue and serve 'a complaint stating its charges in that respect' whenever it has reason to believe that a concern 'has been or is using' such methods. The function of the complaint is solely to advise the respondent of the charges made so that he may have due notice and full opportunity for a hearing thereon. It does not purport to set out the elements of a crime like an indictment or information, nor the elements of a cause of action like a declaration at law or a bill in equity. All that is requisite in a complaint before the Commission is that there be a plain statement of the thing claimed to be wrong so that the respondent may be put upon his defense. The practice of the Federal Trade Commission in this respect, as in many others, is modeled on that which has been pursued by the Interstate Commerce Commission for a generation and has been sanctioned by this as well as the lower federal courts."103b

Gregory Hankin

George Washington University,

Washington, D. C.

103b Idem, p. 429. 